\title{
Deoxyribonucleoside-requiring Mutants of Bacillus subtilis
}

\author{
By B. K. RIMA* AND I. TAKAHASHI \\ Department of Biology, McMaster University, Hamilton, Ontario L8S 4K1, Canada
}

(Received 14 February 1978)

\begin{abstract}
A number of deoxyribonucleoside-requiring mutants (dns) of Bacillus subtilis were isolated and their growth characteristics and ribonucleotide reductase activities were compared with those of the wild type and of a dna mutant ( $t s A 13)$. Both $t s A 13$ and $d n s$ mutants required the presence of a mixture of deoxyribonucleosides for growth at $45^{\circ} \mathrm{C}$ but not at $25^{\circ} \mathrm{C}$. All the mutant strains tested contained ribonucleotide reductase activity which showed heat sensitivity similar to that of the enzyme from a wild-type strain. The reductase in B. subtilis seemed to reduce ribonucleoside triphosphates in a similar manner to the enzyme in Lactobacillus leichmannii.
\end{abstract}

\section{INTRODUCTION}

In bacterial and mammalian cells, ribonucleotides are converted to corresponding deoxyribonucleotides by ribonucleotide reductase (O'Donovan \& Neuhard, 1970). In Escherichia coli, ribonucleoside diphosphates are the substrate for this enzyme (Larsson \& Reichard, 1966), and in Lactobacillus leichmannii, ribonucleoside triphosphates are reduced to the corresponding deoxyribonucleotides (Goulian \& Beck, 1966).

Fuchs \& Neuhard (1973) described a mutant of E. coli which is affected in ribonucleoside diphosphate reductase. Other mutants affected in this enzyme have been isolated as temperature-sensitive dna mutants of E. coli (Fuchs et al., 1972) and of B. subtilis (Bazill \& Karamata, 1972). Since $E$. coli lacks deoxyribonucleoside kinase (Karlstrøm, 1970), the addition of deoxyribonucleosides does not support growth of mutants affected in ribonucleotide reductase. In contrast. B. subtilis contains deoxyribonucleoside kinase (Bazill \& Karamata, 1972; Rima \& Takahashi, 1973, 1977) and therefore mutants of $B$. subtilis affected in ribonucleotide reductase could possibly be obtained by isolating deoxyribonucleosiderequiring clones.

In the present paper, the isolation and growth characteristics of a number of such mutants is described and ribonucleotide reduction in the mutants is compared with that in the wild type and in one of the temperature-sensitive dna mutants of Bazill \& Karamata (1972).

\section{METHODS}

Symbols and abbreviations. Genetic symbols used are: dns, mutants requiring deoxyribonucleosides; $p y r$, blocked in the de novo synthesis of UMP; $t s A$, temperature-sensitive DNA synthesis; $c d d$, deoxycytidinecytidine deaminase; $d c k$, deoxycytidine kinase; $d d d$, deoxycytidylate deaminase (Rima \& Takahashi, 1978); thy $A$, thymidylate synthetase: thy $B$, an unknown enzyme involved in thymidylate synthesis (Wilson, Farmer \& Rothman, 1966; Rima \& Takahashi, 1978). Other abbreviations are: Ade, adenine; Gua, guanine; Thy, thymine ;Cyt, cytosine; Ura, uracil; Cyd, cytidine; dCyd, deoxycytidine; dUrd, deoxyuridine; dGuo, deoxyguanosine; dAdo, deoxyadenosine; dThd, thymidine; NdR, dAdo + dGuo+dCyd + dThd.

Bacterial strains. The bacterial strains, their growth characteristics and the media have been described before (Rima \& Takahashi, 1977, 1978).

* Present address: Department of Biochemistry, The Queen's University of Belfast, Belfast BT9 7BL, Northern Ireland. 
Assay of ribonucleotide reductase. Crude extracts for the assay of ribonucleotide reductase were prepared as follows. Cells of $\boldsymbol{B}$. subtilis were grown to late exponential phase in Difco Penassay Broth and were harvested by centrifugation. The cells were resuspended in $50 \mathrm{~mm}$-potassium phosphate buffer $(\mathrm{pH} 7 \cdot 4)$ containing $0.2 \mathrm{~mm}-\beta$-mercaptoethanol. The cell suspension was treated twice with a French pressure cell at $103 \mathrm{MPa}$. Unbroken cells and debris were removed by centrifuging at $30000 \mathrm{~g}$ for $30 \mathrm{~min}$ and the supernatant fluid was used as crude extract. The concentration of protein in the extracts was determined by the method of Lowry et al. (1951).

The reaction mixture for the assay of UTP reductase contained (in $1.0 \mathrm{ml}$ ): $25 \mathrm{~mm}$-potassium phosphate buffer (pH 7.4), 1 mM-dithiothreitol, $1 \cdot 2 \mathrm{mM}^{-\mathrm{CaCl}_{2}}, 0.285 \mu \mathrm{M}$-[5- $\left.{ }^{3} \mathrm{H}\right] \mathrm{UTP}(5 \mu \mathrm{Ci})$ and crude extract corresponding to $3.5 \mathrm{mg}$ protein. The reaction mixture was incubated at $37^{\circ} \mathrm{C}$ and the reaction was terminated after $10 \mathrm{~min}$ by heating at $100^{\circ} \mathrm{C}$ for $3 \mathrm{~min}$. The resulting precipitates were removed by centrifugation and $30 \mu \mathrm{l}$ of the supernatant fluid was spotted on Whatman no. 1 paper together with unlabelled reference nucleotides and nucleosides. Products of the reaction were separated by paper chromatography using a mixture of $95 \%$ ethanol/saturated sodium tetraborate/5 M-ammonium acetate/0.5 M-EDTA (220:80:20:0.5, by vol.) as solvent. The enzyme activity was calculated from the amount of product formed after $10 \mathrm{~min}$ at $37^{\circ} \mathrm{C}$.

The reaction mixture for CTP reductase contained (in 1.0 ml): $25 \mathrm{mM}$-potassium phosphate buffer (pH 7.4), $15 \mathrm{~mm}-\mathrm{MgCl}_{2}, 30 \mu \mathrm{mol}$ creatine phosphate, $0.05 \mathrm{mg}$ creatine phosphokinase, $0.255 \mu \mathrm{M}$ - $\left[5-{ }^{3} \mathrm{H}\right] \mathrm{CTP}$ $(5 \mu \mathrm{Ci})$ and crude extract corresponding to 0.5 to $1.0 \mathrm{mg}$ protein. The amount of product formed in the reaction mixture during $10 \mathrm{~min}$ incubation at $37^{\circ} \mathrm{C}$ was determined as described for UTP reductase.

\section{RESULTS AND DISCUSSION}

\section{Isolation of dns mutants}

Cells of B. subtilis contain deoxyribonucleoside kinase (Bazill \& Karamata, 1972; Rima \& Takahashi, 1977) and therefore mutants affected in deoxyribonucleotide synthesis might be obtained as deoxyribonucleoside-requiring clones (dns mutants). In order to isolate such mutants, strains $\mathrm{SB} 19 \mathrm{E}$ (prototrophic) and $\mathrm{A} 26$ (pyr-1) were mutagenized with $N$-methyl- $N^{\prime}$-nitro- $N$-nitrosoguanidine as described earlier (Rima \& Takahashi, 1977). Mutagenized clones were plated on MMC medium supplemented with dAdo, dCyd, dGuo and dThd (NdR), each at $20 \mu \mathrm{g} \mathrm{ml}^{-1}$. With $B$. subtilis A26, Ura was also added to the above synthetic medium (MMC) at $10 \mu \mathrm{g} \mathrm{ml}^{-1}$. Colonies developed and were replica-plated on MMC agar without NdR and those that failed to grow were tested for NdR requirement. By this technique, eight mutants which required $\mathrm{NdR}$ for growth at $37^{\circ} \mathrm{C}$ were obtained. This type of mutant occurred at a frequency of about $0.07 \%$ after mutagenesis with nitrosoguanidine. The minimum requirement for growth of these strains was a combination of dAdo or dGuo plus dCyd. dThd could not replace dCyd as it cannot be converted to dCTP (see Fig. 1). In agreement with Bazill \& Karamata (1972), we also found that any deoxyribonucleoside plus three bases (for example, dCyd + Ade + Gua + Thy) did not fulfil the growth requirement of these strains. This indicated that $B$. subtilis, unlike L. leichmannii, does not contain trans- $N$-deoxyribosylase (Beck \& Levin, 1963).

The response of the dns mutants to addition of $\mathrm{NdR}$ was compared with that of the $t s A 13$ mutant at 25,30 and $45^{\circ} \mathrm{C}$ (Table 1 ). The $d n s$ mutants and $t s A 13$ required $\mathrm{NdR}$ for growth at $45^{\circ} \mathrm{C}$ and strain $t s A 13 c d d-1 d c k-3$, which lacks deoxycytidine kinase, could not grow at $45^{\circ} \mathrm{C}$ even in the presence of $\mathrm{NdR}$. This confirms that the $t s A 13$ mutation affects the synthesis of deoxyribonucleotides. At $30^{\circ} \mathrm{C}$, mutants $d n s-2$ and $d n s-3$ grew in the absence of $\mathrm{NdR}$ and they resembled the $t s A 13$ mutant in the temperature sensitivity of the $\mathrm{NdR}$ requirement. At $25^{\circ} \mathrm{C}$, all $d n s$ mutants grew in the absence of $\mathrm{NdR}$. The growth response of $d n s-5, d n s-6, d n s-7$ and $d n s-8$ (not shown) was similar to $d n s-1$. Fuchs \& Neuhard (1973) reported that the dUrd-requiring mutants of $E$. coli grew in the absence of dUrd at low temperatures and under other conditions which resulted in slow growth. It is possible that the $t s A$ and $d n s$ mutants of $B$. subtilis are similarly 'leaky' in their requirement for deoxyribonucleosides. 


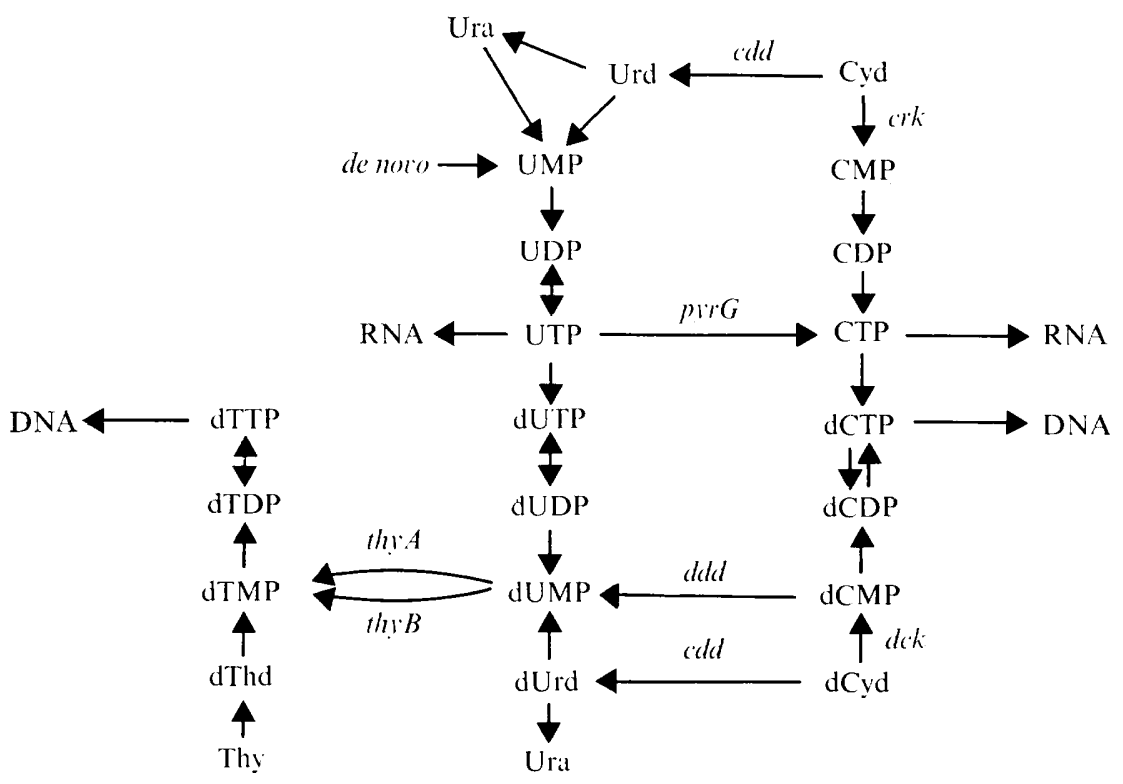

Fig. 1. Metabolism of pyrimidine compounds in B. subtilis.

Table 1. Effect of temperature and deoxyribonucleosides on the growth of dns and tsA mutants

MMC medium comprised Spizizen's minimal medium (Spizizen, 1958) plus 0.02\% (w/v) Difco Casamino acids. $\mathrm{NdR}$ were added at $20 \mu \mathrm{g} \mathrm{ml}^{-1}$.

\begin{tabular}{|c|c|c|c|c|c|}
\hline \multirow[b]{2}{*}{ Strain } & \multirow{2}{*}{$\begin{array}{c}\text { At } 25^{\circ} \mathrm{C} \\
\text { MMC }\end{array}$} & \multicolumn{2}{|c|}{ At $30^{\circ} \mathrm{C}$} & \multicolumn{2}{|c|}{ At $45^{\circ} \mathrm{C}$} \\
\hline & & MMC & $\mathrm{MMC}+\mathrm{NdR}$ & MMC & $\mathrm{MMC}+\mathrm{NdR}$ \\
\hline $\begin{array}{l}\text { tsA13 cdd-1 } \\
\text { tsA13 cdd-1 dck-3 }\end{array}$ & $\begin{array}{l}++ \\
++\end{array}$ & $\begin{array}{l}+ \\
+\end{array}$ & $\begin{array}{l}+ \\
+\end{array}$ & $\begin{array}{l}- \\
-\end{array}$ & $\begin{array}{l}+ \\
-\end{array}$ \\
\hline $\begin{array}{l}\text { A26 (pyr-1) } \\
\text { A26 dns-1 }\end{array}$ & $\begin{array}{c}++ \\
\pm\end{array}$ & $\begin{array}{c}++ \\
-\end{array}$ & $\begin{array}{c}++ \\
+\end{array}$ & $\begin{array}{c}++ \\
-\end{array}$ & $\begin{array}{c}++ \\
+\end{array}$ \\
\hline $\begin{array}{l}\text { SB19E (wild type) } \\
\text { SB19E } d n s-2 \\
\text { SB19E } d n s-3 \\
\text { SB19E } d n s-4\end{array}$ & $\begin{array}{l}++ \\
++ \\
++ \\
\pm\end{array}$ & $\begin{array}{l}++ \\
+ \\
+ \\
+\end{array}$ & $\begin{array}{l}++ \\
++ \\
++ \\
++\end{array}$ & $\begin{array}{c}++ \\
- \\
\pm \\
-\end{array}$ & $\begin{array}{l}++ \\
++ \\
+ \\
+\end{array}$ \\
\hline
\end{tabular}

\section{Ribonucleotide reductase of $B$. subtilis}

Ribonucleotide reductase of $B$. subtilis has not been characterized previously and the following experiments were carried out to establish whether the enzyme reduces nucleoside di- or triphosphates. In $B$. subtilis strain $\mathrm{SB} 19 \mathrm{E}$, the reductase activity was determined with $\left[{ }^{3} \mathrm{H}\right] \mathrm{CMP},\left[{ }^{3} \mathrm{H}\right] \mathrm{CDP}$ and $\left[{ }^{3} \mathrm{H}\right] \mathrm{CTP}$ as substrate. No activity was detectable with $\left[{ }^{3} \mathrm{H}\right] \mathrm{CMP}$. The activities with $\left[{ }^{3} \mathrm{H}\right] \mathrm{CDP}$ and $\left[{ }^{3} \mathrm{H}\right] \mathrm{CTP}$ were 13 and $62 \mathrm{pmol} \mathrm{h}{ }^{-1}$ (mg protein) $)^{-1}$, respectively. The product of the reaction was $\mathrm{dCTP}$ and practically no radioactivity was found in dCDP, dCMP and dCyd. The rate of product formation was not constant with time and the reaction stopped after $10 \mathrm{~min}$ incubation. This appeared to be due to breakdown of the substrate, as $\left[{ }^{3} \mathrm{H}\right] \mathrm{CTP}$ in the reaction mixture was rapidly converted to CMP (Fig. 2). Therefore, in later experiments, CTP in the reaction mixture was protected by addition of creatine phosphate and creatine phosphokinase. This modification led to a 10-fold increase in the level of CTP reduction in crude extracts of $B$. subtilis. 


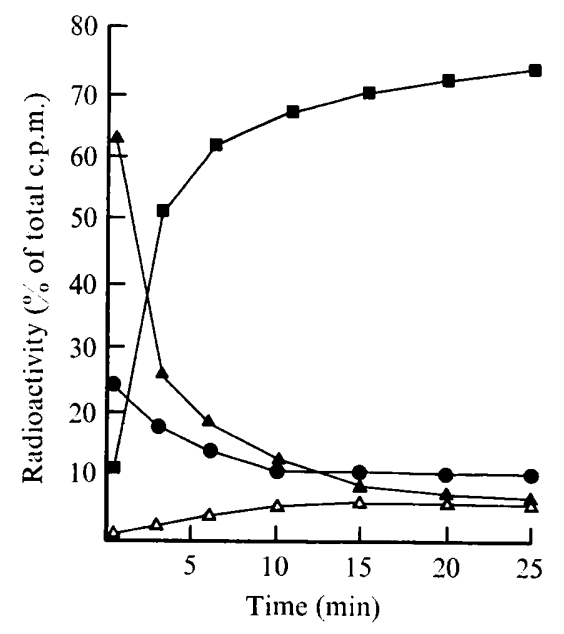

Fig. 2. Breakdown of $\left[{ }^{3} \mathrm{H}\right] \mathrm{CTP}$ in the reaction mixture for CTP reductase. The composition of the reaction mixture was as described in Methods except that creatine phosphate and creatine phosphokinase were absent. $\triangle$, CTP; $\triangle$, dCTP; $\bullet$, CDP, $\square$, CMP.

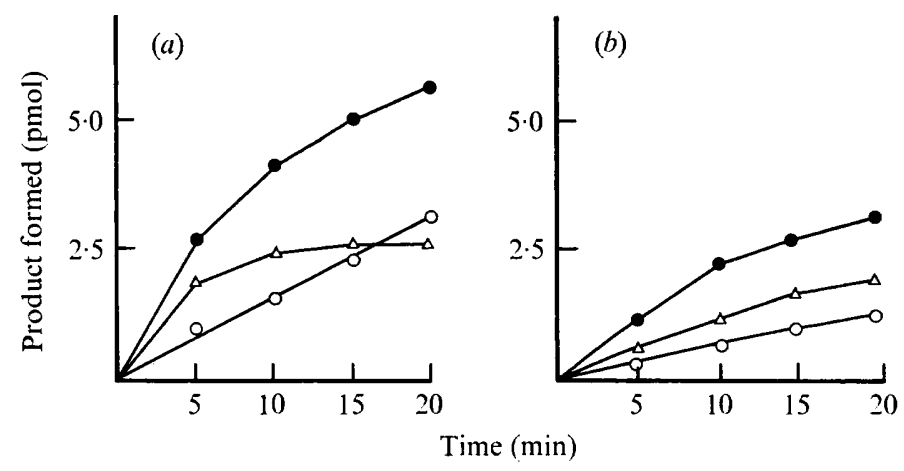

Fig. 3. Formation of dUTP and dUDP in the reaction mixture for UTP reductase. The concentrations of protein added to the reaction mixture in $(a)$ and $(b)$ were 7.0 and $1.75 \mathrm{mg} \mathrm{ml}^{-1}$, respectively. No dUMP was synthesized. $\triangle$, dUTP; $O$, dUDP; $\bullet$, total dUTP + dUDP.

With uridine ribonucleotides, substrate stability was also found to be a problem in ribonucleotide reductase assays. The addition of creatine phosphate and creatine phosphokinase did not alter the rate of uridine ribonucleotide reduction [about $7 \mathrm{pmol} \mathrm{h}^{-1}(\mathrm{mg}$ protein $)^{-1}$ with UDP or UTP as substrate] as markedly as for CTP reduction. No dUMP was synthesized. The formation of dUTP and dUDP from the reduction of UTP is illustrated in Fig. 3. At a relatively high protein concentration, the formation of dUTP stopped after $10 \mathrm{~min}$ (Fig. $3 a$ ). At lower protein concentration, however, dUTP was produced continuously at a higher rate than dUDP (Fig. $3 b$ ). The apparent cessation of dUTP formation and the presence of dUDP in the reaction mixture are probably due to the action of dUTPase which produced predominantly dUDP in $B$. subtilis (Tomita \& Takahashi, 1976).

In the only other study on the ribonucleotide reductase in a Bacillus species, Yau \& Wachsman (1973) were unable to determine whether di- or triphosphates are the substrate for the enzyme, but they did not protect the substrate and got similar activity with either CTP or CDP as substrate. Our results suggest that ribonucleoside triphosphates are the substrate for reduction in $B$. subtilis and the enzyme may therefore resemble the ribonucleotide reductase of $L$. leichmannii (Goulian \& Beck, 1966). 
Table 2. Growth inhibition of dns and ts A mutants by hydroxyurea at $30^{\circ} \mathrm{C}$

$\mathrm{NdR}$ were added to MMC agar at $10 \mu \mathrm{g} \mathrm{ml}^{-1}$ where indicated (-, absent; +, present). Symbols for growth are as defined in Table 1.

$\begin{array}{ccccc}\begin{array}{c}\text { Hydroxyurea } \\ \text { concn } \\ \text { (mM) }\end{array} & \text { NdR } & \begin{array}{c}\text { SB19E } \\ \text { (wild type) }\end{array} & t s A 13 c d d-1 & t s A 13 c d d-1 d c k-3 \\ 0 & - & ++ & ++ & ++ \\ 1 & - & ++ & ++ & ++ \\ 3 & - & ++ & ++ & ++ \\ 10 & - & ++ & + & \pm \\ 30 & - & - & - & - \\ 60 & - & - & - & - \\ 100 & - & - & + & - \\ 60 & + & + & + & - \\ 100 & + & + & & \end{array}$

The ribonucleotide reductase activity in $L$. leichmannii and B. megaterium is stimulated by the addition of cobalamin (vitamin $\mathrm{B}_{12}$ ) (Goulian \& Beck, 1966; Yau \& Wachsman, 1973). However, we found that optimum activity was obtained with the reaction mixture described and cobalamin addition to crude extracts did not enhance reductase activity.

The enzymes in $E$. coli and $L$. leichmannii differ in sensitivity to hydroxyurea (HU). The reductase in $E$. coli is inhibited by HU in vitro and in vivo (Elford, 1968; Sinha \& Snustadt, 1972). The enzyme in L. leichmannii is not sensitive to HU in vitro and the in vivo effect was not reported (Elford, 1968). We found that CTP and UTP reductase activity in B. subtilis was not inhibited in vitro by $\mathrm{HU}$ at concentrations ranging from $0 \cdot 1$ to $10 \mathrm{mM}$. In vitro, $\mathrm{HU}$ inhibits ribonucleotide reductase in B. megaterium only slightly if at all (Yau \& Wachsmann, 1973). Therefore, the enzyme in $B$. subtilis appeared to respond in vitro to $\mathrm{HU}$ in a similar way to the other ribonucleoside triphosphate reductases. However, in vivo, the growth of B. subtilis was inhibited by HU (Table 2). Our results confirm and expand those of Bazill \& Karamata (1972). Strains carrying the $t s A 13$ mutation appeared to be inhibited by lower concentrations of $\mathrm{HU}$ and the addition of $\mathrm{NdR}$ to the medium overcame the inhibitory effect. However, in a strain containing the $d c k$ mutation, which lacks dCyd kinase, $\mathrm{NdR}$ was unable to overcome the effect of $\mathrm{HU}$. This indicates that $\mathrm{NdR}$ counteract the effect of HU after they have been phosphorylated to deoxyribonucleotides, suggesting that HU interferes with the supply of deoxyribonucleotides. These results indicate that, in vivo, ribonucleotide reduction in $B$. subtilis is sensitive to $\mathrm{HU}$, even though we were unable to demonstrate this effect in vitro.

\section{Ribonucleotide reductase in mutant strains}

In order to investigate whether ribonucleotide reductase activity was affected by the presence of the $t s A 13$ mutation, CTP and UTP reductase activity was assayed in strains 167 thy $A$ thy $B$ and 167 ts $A 13$ thy $A$ thy $B$ obtained from Bazill \& Karamata (1972). There was no significant difference in reductase activity between the two strains grown either at $37^{\circ} \mathrm{C}$ in the absence of $\mathrm{NdR}$ or at $45^{\circ} \mathrm{C}$ in the presence of $\mathrm{NdR}\left(10 \mu \mathrm{g} \mathrm{ml}{ }^{-1}\right)$.

To compare the temperature sensitivity of the reductase in vitro, the above $t s^{+}$and $t s A 13$ strains were grown at $37^{\circ} \mathrm{C}$ in Penassay Broth and CTP and UTP reductase activities were assayed at 37 and $45^{\circ} \mathrm{C}$. The activity of UTP reductase in the $t s^{+}$strain assayed at $45^{\circ} \mathrm{C}$ was $54 \%$ of the activity at $37^{\circ} \mathrm{C}$. The activity of UTP reductase in the $t s A 13$ strain assayed at $45{ }^{\circ} \mathrm{C}$ was $59 \%$ of that assayed at $37^{\circ} \mathrm{C}$. The presence of the $t s A 13$ mutation therefore had no appreciable effect on the temperature sensitivity of the enzyme in vitro. In the case of CTP reduction, enzyme activities in both $t s^{+}$and $t s A 13$ strains at $45^{\circ} \mathrm{C}$ were not significantly different from those determined at $37^{\circ} \mathrm{C}$. 
Table 3. Activity of CTP reductase in dns and tsA mutants

\begin{tabular}{|c|c|c|}
\hline Strain & $\begin{array}{c}\text { CTP } \\
\text { reductase } \\
\text { activity }\end{array}$ & $\begin{array}{c}\text { CTP } \\
\text { reductase } \\
(\% \text { of } \\
\text { parent strain) }\end{array}$ \\
\hline $\mathrm{SB} 19 \mathrm{E}$ (prototrophic) & $1 \cdot 26$ & 100 \\
\hline$d n s-2$ & 0.77 & 61 \\
\hline$d n s-3$ & 0.29 & 23 \\
\hline$d n s-4$ & $1 \cdot 24$ & 98 \\
\hline tsA13 cdd-1 & 1.06 & 85 \\
\hline A26 (pyr-1) & $1 \cdot 61$ & 100 \\
\hline A26 dns-1 & 0.76 & 44 \\
\hline
\end{tabular}

Table 4. Phenotypic reversion of the tsA13 mutation

$\mathrm{NdR}$ were added to $\mathrm{MMC}$ agar at $10 \mu \mathrm{g} \mathrm{ml}^{-1}$. Thy was added at $10 \mu \mathrm{g} \mathrm{ml}^{-1}$ for thy $A$ thy $B$ mutants. Symbols for growth are as defined in Table 1 .

\begin{tabular}{|c|c|c|c|}
\hline Strain & $\begin{array}{c}\mathrm{MMC} \\
\text { at } 37^{\circ} \mathrm{C}\end{array}$ & $\begin{array}{c}\text { MMC } \\
\text { at } 45^{\circ} \mathrm{C}\end{array}$ & $\begin{array}{c}\mathrm{MMC}+\mathrm{NdR} \\
\text { at } 45^{\circ} \mathrm{C}\end{array}$ \\
\hline 167 tsA13 thy $A$ thy $B$ & ++ & - & + \\
\hline 167 tsA13 thyA thy $B^{+}$ & ++ & - & + \\
\hline 167 ts $A 13$ thy $A^{+}$thy $B$ & ++ & - & + \\
\hline 167 tsA13 cdd-1 thy $A$ thy $B$ & ++ & + & + \\
\hline 167 ts A13 cdd-1 thy $A^{+}$thy $B$ & ++ & + & + \\
\hline 167 tsA13 cdd-1 thy A thyB $B^{+}$ & ++ & - & + \\
\hline tsA13 cdd-1 & ++ & - & + \\
\hline$t s A 13 c d d-1 d d d-3$ & ++ & + & + \\
\hline
\end{tabular}

To investigate whether the requirement of $d n s$ mutants for $\mathrm{NdR}$ was reflected in reduced levels of ribonucleotide reductase activity in the mutants, CTP reductase was assayed in extracts of the dns mutants. They showed a considerable amount of CTP reductase activity varying from 23 to $98 \%$ of the activity in the parent strains (Table 3 ). The assayable reductase activities found in crude extracts of $B$. subtilis were very low and they may not be representative of the activity of the enzyme in vivo. This might explain why the requirement for NdR of the $t s A$ and $d n s$ mutants did not correlate with the levels of assayable reductase activity in these strains, and the fact that all these strains were able to grow at low temperature in the absence of $\mathrm{NdR}$ may indicate that all our mutants can reduce ribonucleotides to some degree.

\section{Suppression of tsA phenotype}

Further evidence for the complex nature of the $\mathrm{NdR}$ requirement in B. subtilis mutants (i.e. none of them appeared to be ribonucleotide reductase negative) was obtained from studies on the effect of other mutations on the $t s A$ phenotype. The growth response to NdR at various temperatures was determined for a number of mutants carrying the $t s A 13$ mutation together with other mutations that affect the metabolism of pyrimidine nucleotides and nucleosides such as $d d d$ (dCMP deaminase), $c d d$ (dCyd-Cyd deaminase), thy $A$ (dTMP synthetase) and thy $B$ (dTMP synthetase) (Fig. 1). It was found that mutants carrying the tsA13 mutation in combination with thyB and $c d d-1$ were able to grow at $45^{\circ} \mathrm{C}$ without $\mathrm{NdR}$ (Table 4). A mutant carrying the $t s A 13$ mutation together with $d d d-3$ and $c d d-1$ was also able to grow at $45^{\circ} \mathrm{C}$ without $\mathrm{NdR}$ (Table 4).

The finding that the $t s A$ phenotype can be reversed by $c d d$ and $d d d$ or $c d d$ and thyB mutations may be explained by the following observation. Bazill \& Karamata (1972) showed that dCTP but not dTTP disappeared rapidly when cells of $t s A 13$ were shifted up to $45^{\circ} \mathrm{C}$. Therefore, mutations such as $c d d$ and $d d d$ which make cells unable to deaminate 
deoxycytidine compounds would suppress the $t s A$ phenotype. It has been suggested that the thy $A$ and thy $B$ mutations may have a different effect on the sizes of various deoxypyrimidine nucleotide pools (Wilson et al., 1966) and this may explain the different effect of these two mutations on the $t s A$ phenotype.

Financial support for this work was provided by a grant from the National Research Council of Canada (A-1996). We wish to thank Darryll Bradford for excellent technical assistance.

\section{REFERENCES}

Bazill, G. W. \& Karamata, D. (1972). Temperature-sensitive mutants of Bacillus subtilis defective in deoxyribonucleotide synthesis. Molecular and General Genetics 117, 19-29.

Beck, W. S. \& Levin, M. (1963). Purification, kinetics and repression control of bacterial trans- $N$-deoxyribosylase. Journal of Biological Chemistry 238, 702-709.

ELFORD, H. (1968). Effect of hydroxyurea on ribonucleotide reductase. Biochemical and Biophysical Research Communications 33, 129-135.

Fuchs, J. A. \& Neuhard, J. (1973). A mutant of Escherichia coli defective in ribonucleoside diphosphate reductase. European Journal of Biochemistry 32, 451-456.

Fuchs, J. A., KarlstrøM, H. O., Warner, H. R. \& ReICHARD, P. (1972). Defective gene product in dnaF mutant of Escherichia coli. Nature New Biology 238, 69-71.

Goulian, M. \& BeCK, W. S. (1966). Purification and properties of a cobamide dependent ribonucleotide reductase from Lactobacillus leichmannii. Journal of Biological Chemistry 241, 4233-4242.

KARLSTRøM, H. O. (1970). Inability of Escherichia coli $\mathrm{B}$ to incorporate added deoxycytidine, deoxyadenosine and deoxyguanosine into DNA. European Journal of Biochemistry 17, 68-71.

Larsson, A. \& Reichard, P. (1966). Enzymatic synthesis of deoxyribonucleotides. X. Reduction of purine ribonucleotides: allosteric behaviour and substrate specificity of the enzyme system from Escherichia coli B. Journal of Biological Chemistry 241, 2540-2543.

Lowry, O. H., Rosebrough, N. J., Farr, A. L. \& Randall, R. J. (1951). Protein measurement with the Folin phenol reagent. Journal of Biological Chemistry 193, 265-275.
O'Donovan, G. A. \& Neuhard, J. (1970). Pyrimidine metabolism in microorganisms. Bacteriological Reviews 34, 278-343.

Rima, B. K. \& TAKahashi, I. (1973). The synthesis of nucleic acids in Bacillus subtilis infected with phage PBS1. Canadian Journal of Biochemistry 51, 1219-1224.

Rima, B. K. \& TAKahashi, I. (1977). Metabolism of pyrimidine bases and nucleosides in Bacillus subtilis. Journal of Bacteriology 129, 574-579.

RIMA, B. K. \& TAKAHASHI, I. (1978). Synthesis of thymidine nucleotides in Bacillus subtilis. Canadian Journal of Biochemistry 56, 158-160.

Sinha, N. K. \& SNustadT, D. P. (1972). Mechanism of inhibition of deoxyribonucleic acid synthesis in Escherichia coli by hydroxyurea. Journal of Bacteriology 112, 1321-1334.

SpIZIZEN, J. (1958). Transformation of biochemically deficient strains of Bacillus subtilis by deoxyribonucleate. Proceedings of the National Academy of Sciences of the United States of America 44, 1072-1078.

Tomita, F. \& TaKahashi, I. (1976). Changes in enzyme activities in Bacillus subtilis infected with bacteriophage PBS1. In Microbiology 1976, pp. 315-318. Edited by D. Schlessinger. Washington: American Society for Microbiology.

Wilson, M. C., Farmer, J. L. \& Rothman, F. (1966). Thymidylate synthesis and aminopterin resistance in Bacillus subtilis. Journal of Bacteriology 92, 186-196.

YaU, S. \& Wachsman, J. T. (1973). The Bacillus megaterium ribonucleotide reductase: evidence for a $\mathrm{B}_{12}$ coenzyme requirement. Molecular and Cellular Biochemistry 1, 101-105. 